\title{
Merchant Steering of Consumer Payment Choice: Evidence from a 2012 Diary Survey
}

\author{
Oz Shy and Joanna Stavins
}

\begin{abstract}
:
This paper seeks to discover whether U.S. merchants are using their recently granted freedom to offer price discounts and other incentives to steer customers to pay with methods that are less costly to merchants. Using evidence of merchant steering based on the 2012 Diary of Consumer Payment Choice, we find that only a very small fraction of transactions received a cash or debit card discount, and even fewer were subjected to a credit card surcharge. Transactions at gasoline stations were more likely to receive either cash discounts or credit card surcharges than transactions in other sectors. Larger-value transactions were somewhat more likely to receive a discount, although the effect is small when controlling for merchant sector. There is little evidence that merchants have started taking advantage of their new flexibility to influence consumers' payment choice by either discounting or surcharging based on the payment method.
\end{abstract}

Keywords: Payment choice, merchant steering, cash and debit discount, credit card surcharge

\section{JEL Classifications: D14}

Joanna Stavins is a senior economist and policy advisor in the Consumer Payments Research Center of the research department of the Federal Reserve Bank of Boston. Oz Shy is a senior economist in the Consumer Payments Research Center of the research department of the Federal Reserve Bank of Boston. Their e-mail addresses are joanna.stavins@bos.frb.org and oz.shy@bos.frb.org, respectively.

This paper, which may be revised, is available on the web site of the Federal Reserve Bank of Boston at http://www.bostonfed.org/economic/wp/index.htm.

We thank Tamás Briglevics, Scott Schuh, and Mingzhu Tai for helpful comments, William Murdock for excellent research assistance, and the diary team for their input.

The views expressed in this paper are those of the authors and do not necessarily represent the views of the Federal Reserve Bank of Boston or the Federal Reserve System.

This version: May 12, 2014

\begin{tabular}{|l|l|l|l|l}
\hline $\mathrm{C}$ & $\mathrm{P}$ & CONSUMER PAYMENTS \\
\hline $\mathrm{R}$ & $\mathrm{C}$ & Research Center
\end{tabular}




\section{Introduction}

Credit card networks charge merchants higher fees for credit card transactions than the costs the merchants incur for accepting other forms of payment. ${ }^{1}$ As discussed in Briglevics and Shy (forthcoming), until recently merchants in the United States were prohibited by their contracts with the credit card networks from using discounts or surcharges to steer customers to pay for their purchases with payment instruments such as debit cards or checks that were less costly to merchants than credit cards, although merchants were allowed to give discounts to customers who paid cash. Recent U.S. legislation and court settlements removed these contractual prohibitions.

In this paper we use the results of the 2012 Diary of Consumer Payment Choice (DCPC) to obtain some early estimates of the degree to which merchants exercised their new freedoms to steer consumers to pay with payment instruments that are less costly to the merchants. In Shy and Stavins (2014) we showed how earlier pilot diaries inadequately attempted to elicit similar information from consumers. In the 2012 larger-sample diary, we revised the questions, aiming to elicit more accurate information about discounting and surcharging by merchants.

Steering consumers to pay with specific payment instruments can be attempted in various ways. The most obvious (but not necessarily profitable) way to steer is to refuse to accept a payment instrument. Some merchants refuse to accept credit cards, or they place a lower limit on the transaction value for which they accept credit cards, because of a relatively high merchant cost of accepting credit cards, compared to cash or debit cards. A second method is simply to ask the buyer to refrain from using a particular instrument. A third option is to provide some incentives, such as reward points, to customers who pay with the payment instrument most desired by the merchant, where the term "desired" generally (but not always) refers to a payment instrument that is less costly to the merchant.

\footnotetext{
${ }^{1}$ See Barron, Staten, and Umbeck (1992) for a history of cash discounts in the U.S. following the 1981 Cash Discount Act H.R. 31, which became Public Law No: 97-25; see http://thomas.loc.gov/cgi-bin/bdquery/z?d097:H.R.31:
} 
The investigation in this paper focuses on two examples of the third steering methodmerchants providing incentives and/or disincentives to consumers:

1. Offering price discounts to buyers who use the merchant's desired payment instrument.

2. Imposing price surcharges on buyers who use the merchant's least desired instrument.

The article is organized as follows: Section 2 provides background information about the recent legislative changes and previous literature. Section 3 describes the diary data used in this study. Section 4 presents the analysis and the results. Section 5 shows the regression model and results. Section 6 concludes.

\section{Background}

On July 13, 2012, the Eastern District Court of New York was asked to approve a class settlement between Visa and MasterCard and a large group of merchants that would allow merchants in the United States to impose surcharges on card transactions. The title of this settlement is Final Judgment as to Defendants Mastercard International Inc. and Visa Inc., Civil Action No. CV-10-4496 (E.D.N.Y. Oct. 4, 2010). ${ }^{2}$

It should be noted that credit card surcharges are still prohibited by some state laws in the United States. On October 3, 2013, a federal judge blocked enforcement of a New York state law that subjects retailers to criminal penalties if they impose surcharges on customers who choose to pay by credit card rather than cash. ${ }^{3}$

In the academic literature, only a few papers investigate whether and to what degree merchants can enhance their profit by providing price discounts on payment instruments that

\footnotetext{
${ }^{2}$ Available at http://www.justice.gov/atr/cases/f262800/262875.htm.

${ }^{3}$ See http://www.reuters.com/article/2013/10/03/us-creditcard-surcharges-lawsuit-idUSBRE9920QQ20131003
} 
are less costly to them. ${ }^{4}$ Ingene and Levy (1982) use a telephone survey sample of 248 respondents to offer hypothetical cash-price discount rates in the range of 0 to 6.5 percent in order to examine the marketing and financial implications of offering a discount aimed at encouraging payment with cash rather than with a credit card. Grant (1985) extends the analysis of Ingene and Levy (1982) by studying how payment instrument choice affects profits when merchants offer a discount. More recently, Briglevics and Shy (forthcoming) estimate whether merchants can enhance their revenue by offering price discounts to buyers who pay with cash or debit cards rather than credit cards. They find the gains to be very small because, under uniform pricing, any discounts are received by all buyers, including those who would pay with cash or debit cards without the discount, and the revenue generated from these customers would fall if their price was discounted because of their choice of payment method.

\section{The Diary Data}

The data used in this analysis are from the Federal Reserve Bank of Boston's Diary of Consumer Payment Choice (DCPC) conducted in October 2012. The DCPC collects data on the dollar value, payment instrument used, and type of expense (consumer expenditure category) of each purchase, to complement the information in the Survey of Consumer Payment Choice (Foster et al. 2009).

Our dataset includes 14,772 observations on individual transactions conducted by 2,468 individuals. Each respondent was asked to provide information on every transaction he or she conducted during a specified three-day period. However, respondents were only asked about any discounts or surcharges related to their in-person and online purchases, not to their bill payments. Because we lack information on steering related to bill payments, we excluded those observations from the dataset, yielding 12,584 transactions conducted by 2,297 respondents. The median transaction value was $\$ 14.04$ and the mean value was $\$ 32.63$. The details on the diary dataset are provided in Table 1.

${ }^{4}$ Several papers have empirically investigated buyers' characteristics associated with their choices of payment instruments; see, for example, White (1975), Bounie (2006), Klee (2008), Foster et al. (2011), Schuh and Stavins (2010), Ching and Hayashi (2010), Simon, Smith, and West (2010), and Arango, Huyhh, and Satetti (2011). 
On each day during the diary period, new respondents began to record their transactions for their designated three-day period in October 2012. This method was used in order to get a representation of a typical month that takes into account variation by day of the week and paydays.

Respondents were asked to answer the following three questions about each of their nonbill transactions:

For transactions where they used cash:

Question 1: Did you receive a discount from the merchant specifically for using cash? [Yes/No]

For transactions where they used a debit card:

Question 2: Did you receive a discount from the merchant specifically for using this debit card? [Yes/No]

For transactions where they used a credit card: 5

Question 3: Did you pay an extra charge, surcharge, or convenience fee to the merchant specifically for using this credit card? [Yes/No]

\section{Which Transactions Were Discounted or Surcharged?}

The diary survey asks respondents whether they received a discount or paid a surcharge on each nonbill transaction they report. However, the data do not capture whether the consumer's decision to use a particular payment method was influenced by the merchant's pricing policy, by other incentives, or regardless of the merchant's policy. Conversely, we cannot determine from the data whether the merchant's steering policy was targeted to a particular consumer or whether it was applied to all consumers. For example, a consumer might walk into a store

\footnotetext{
${ }^{5}$ Although the questions refer to the specific debit card or credit card that was used in the transaction, Shy (2013) showed that consumers tend to use only one card.
} 
intending to use a credit card, but after seeing a notice about credit card surcharges the consumer may change his mind and pay cash instead. Our data do not allow us to trace the sequence of events that preceded an individual transaction. Therefore, the data presented here cannot inform us about the causality of payment decisions, but only about correlations between discounting and surcharging by merchant type and consumers' payment choice. Finally, the questions in the dataset concerning discounting for using a debit card and surcharging for using a credit card were framed in terms of use of the specific card and not in terms of the use of the type of card (debit or credit), so some consumers may have responded in the negative when they might have responded in the affirmative if they had interpreted the questions as referring to the type of card. As a result, inferences drawn from responses to these questions may understate consumers' perceptions of attempted steering.

\subsection{Cash discount}

When asked whether they received a discount on a transaction specifically for using cash, respondents said yes for only 1.7 percent of the transactions (column labeled "Cash Discount" in Table 2). The fraction was higher for less educated and for lower-income consumers, although only the differences across income groups were statistically significant.

A breakdown by transaction category (Table 3) shows that auto related and general merchandise transactions had the highest fraction of cash discounts (6.6 percent and 3.5 percent, respectively) among the broad consumption categories. Looking at the finer merchant breakdown (categories listed in the appendix; data not shown), we find that gasoline stations (included in auto) had the highest rate of transactions with cash discounts -8.7 percent, followed by clothing and accessories stores (included in general merchandise) at 7.3 percent. In addition, 9.8 percent of repair/maintenance of electronics and household goods transactions were reported to have received a cash discount. We suspect that these were payments to contractors or repairmen at consumers' homes, but the survey does not provide this level of detail on the location of transactions. The repair transactions are included in a broader category of financial, professional, and miscellaneous services, and they constitute a small part of the 
broad category: only 1.9 percent of transactions in the broad services category received a cash discount.

The top panel in Figure 1 plots the percentage of transactions receiving a cash discount by the value of the transaction. The median value of a cash transaction where a consumer received a discount was $\$ 20$, and it was statistically significantly higher than the median value of a cash transaction with no discount, which was $\$ 7.49$ (Table 3). Note that for every demographic group, the median value of a transaction that received a cash discount is greater than the median value of a transaction that did not receive a discount (Table 2). There is more variation between discounted and nondiscounted transactions by merchant category. For example, the median value of an auto-related transaction with a cash discount is about twice the median value of an auto-related transaction with no cash discount. But in the services category, the median value of a transaction receiving a cash discount is over four times greater than the median value of a nondiscounted transaction. Unfortunately, we cannot determine from the data whether merchants offer discounts only for transactions over a certain value, or whether consumers who like discounts tend to select merchants who offer discounts, and use cash at places where others choose to use other payment methods and forego the discount. In the latter case, merchants might offer discounts for cash transactions of any value.

One reason for a higher prevalence of cash discounts among lower-income consumers (those with income below $\$ 25 \mathrm{~K}$ a year) is that these customers are more likely than consumers with higher incomes to conduct a significantly higher fraction of their transactions at gas stations and clothing stores-places where cash discounts are more likely to be offered.

\subsection{Debit card discount}

The column labeled "Debit Discount" in Table 2 shows that debit card discounts were similarly rare-only 1.8 percent of debit transactions were discounted specifically for using the consumer's debit card. It is somewhat surprising that cash and debit discounting is similarly frequent (the fraction of discounted debit transactions is not statistically different from the fraction of discounted cash transactions). However, debit discounts were recorded in different 
merchant categories than cash transactions, so it is unlikely that the same merchants offer both types of discounts. Moreover, it is possible, as mentioned earlier, that the estimates of discounting for using debit are understated because of the way the question underlying the data was framed.

Less educated consumers were again more likely to receive a discount. Among the merchant categories, Table 3 shows that housing-related transactions were most likely to receive debit card discounts, with respondents stating that 11.3 percent of their housing-related transactions received a discount specifically for using a debit card. These included a broad range of merchants (see the appendix): furniture and home goods stores, appliance and electronics stores, and hardware and garden stores.

The bottom panel of Figure 1 plots the percentage of transactions receiving a debit card discount by the value of the transaction. Even though the percentages are slightly higher for larger-value transactions, the difference across transaction values is not as evident as it is for cash discounts. Nevertheless, the median value of a discounted debit transaction was significantly higher than the median value of a nondiscounted debit transaction: \$27.95 and $\$ 20.52$, respectively (not shown). Although the ratio of the median discounted value to the median nondiscounted value is generally smaller for debit cards than for cash transactions, in the housing-related category-the category with the highest prevalence of debit card discounts - the ratio is greater: the median value of a housing debit card transaction with a discount is 2.7 times as great as the median value of a housing cash transaction without a discount.

\subsection{Credit card surcharge}

In addition to questions about discounts, we asked respondents whether they had to pay any surcharges or other fees for paying with their credit card. Because merchants had been forbidden to surcharge by the credit card networks until recently, surcharging is still very rare and is even less common than discounting for paying with cash: as Table 2 shows, only 1.2 percent of all credit card transactions were reported to have been surcharged or charged other 
fees specifically because the transaction was conducted using the consumer's credit card, a significantly smaller fraction than the fraction of either cash or debit transactions that were discounted. The youngest and least educated respondents reported the highest fraction of credit card transactions with charges or surcharges. Here again, the estimates may be understated because of the wording of the question underlying the data.

Looking at the finer merchant breakdown (not shown in Table 3), we find that gas stations and tolls are the two payment categories with relatively high rates of surcharging: 5.7 and 5.9 percent, respectively. Note that most gas stations post higher prices for credit card purchases than for cash purchases, a practice that can be interpreted either as offering a cash discount or as imposing a credit card surcharge. However, the actual transactions are distinguishable in retrospect, because only a cash transaction could have received a cash discount, and only a credit card transaction could have been surcharged. In addition, 13.7 percent of building services transactions and 7.5 percent of mail, delivery, and storage services transactions were charged a credit card surcharge, although the absolute number of transactions in the building services category is very small. As with cash and debit discounts, the median value of surcharged transactions was significantly higher than the median value of nonsurcharged transactions: $\$ 30$ versus $\$ 26$.

It is not obvious why merchants in certain sectors offer discounts or surcharges more frequently than merchants in others. Gasoline stations have traditionally charged more for credit card transactions and less for cash, and therefore consumers are more likely to accept price differences there, but no other sector can be described this way. Small businesses, which may include repair and maintenance services (which tend to use cash discounts) and storage and delivery services (which tend to use credit card surcharges), may be more likely to steer their customers than larger merchants, because they have more flexibility to adjust prices, since printing and posting prices is likely less onerous and they may not have to ensure uniform pricing across multiple locations. Larger merchants, especially those with many stores, may be 
more reluctant to introduce price changes, as they face higher menu costs and it is more difficult for them to reverse their price changes quickly if they turn out to be unprofitable.

\section{Regressions}

We use regression analysis to estimate the effects of income, demographic variables, and merchant type on the probability of each respondent's receiving a discount or surcharge. Above we showed that there are differences across consumers with various income or demographic attributes as to how likely they are to receive a discount or a surcharge. We also found that transactions conducted at gasoline stations are more likely than transactions in other sectors to have received cash discounts or credit card surcharges. Regressions allow us to test whether the merchant sector and/or demographic attributes affect the probability that a transaction will receive a discount or surcharge, controlling for the respondents' other attributes.

Although the diary dataset is a longitudinal panel-three diary days with multiple transactions for most of the respondents - the rarity of observed steering limits the value and usefulness of the longitudinal nature. The consumer's choice of payment instrument and the merchant's steering are both endogenous and related, so these require a structural model of payment instrument supply and demand. Our econometric specification is chosen to avoid these difficulties and still be able to identify the multivariate impact of the dependent variables. We collapse the longitudinal panel to a cross-section with a single observation per respondent, by aggregating variables over diary days (from 1 day to 3 days).

Although some respondents report having received more than one cash discount or debit card discount, and one respondent paid credit card surcharges on two separate transactions, the majority of respondents who reported either a discount or a surcharge reported only one such transaction (Table 4). In percentage terms, fewer than 16 percent of respondents who reported receiving any cash discounts received more than one cash discount during the three-day period, 10 percent of respondents who reported receiving debit card discounts received more than one debit card discount, and fewer than 5 percent of respondents 
who reported paying credit card surcharges paid more than one surcharge. The infrequent occurrence of multiple discounts and surcharges in the sample limits the value of modeling the reason for multiple discounts. A longer diary period per consumer would be needed to observe much about the nature of consumers receiving multiple discounts.

The sample on which the regressions were run includes all the respondents who conducted at least one transaction during the three-day diary period. Only those who reported having a debit card with them were included in the debit card discount regression, and only those who reported having a credit card with them were included in the credit card surcharge regression.

We estimate three probit regressions: probability of receiving a cash discount, probability of receiving a debit card discount, and probability of paying a credit card surcharge:

$$
\begin{aligned}
& D_{i}^{h}=h\left(N U M_{i}, D C_{i}, C C_{i}, D E M_{i}, S E C_{i j}\right) \\
& D^{d}{ }_{i}=d\left(N U M_{i}, D E M_{i}, S E C_{i j}\right) \\
& S_{i}=s\left(N U M_{i}, D E M_{i}, S E C_{i j}\right)
\end{aligned}
$$

where $D^{h}{ }_{i}$ is a dummy variable equal to 1 if consumer $i$ received at least one cash discount, and $D^{d}{ }_{i}$ is a dummy variable equal to 1 if consumer $i$ received at least one debit card discount; $S_{i}$ is a dummy variable equal to 1 if consumer $i$ paid a credit card surcharge; $N U M_{i}$ is the number of transactions conducted by consumer $i$ during the three-day diary period (conducting more transactions raises the likelihood of receiving a discount or a surcharge); $D C_{i}$ and $C C_{i}$ are dummy variables indicating whether consumer $i$ carried a debit card or a credit card with him on the day he conducted the transactions (to test whether having access to alternative forms of payment affected the outcome); $D E M_{i}$ is a set of demographic variables for consumer $i$ (age, education, income, race, employment status, household size); $S E C_{i j}$ is the proportion of 
consumer $i$ 's transactions conducted in merchant sector $j$ (food, auto, or general merchandise); all the remaining sectors were combined into "other" and were in the omitted category, as very few transactions were conducted in the other sectors).

\subsection{Results}

The regression results are shown in Table 5. The values reported in the table are the marginal effects calculated from the estimated probit coefficients. The cash discount regression has 2,290 respondents, the debit card discount regression has 1,544 debit card holders, and the credit card surcharge regression has 1,212 credit card holders. Recall that we excluded bill payments from the estimation.

Not surprisingly, the more transactions a person conducted, the higher the probability that he received a discount or a surcharge. The number-of-transactions variable is significant in all three regressions.

Consumers in households with annual income of $\$ 25 \mathrm{~K}$ or less were 3.8 percent more likely to receive a cash discount than the omitted category of $\$ 50 \mathrm{~K}-\$ 74 \mathrm{~K}$. The data do not tell us anything about causality of this income effect: it is possible that lower-income consumers are more likely to seek out merchants who offer discounts, or that lower-income consumers are more price sensitive and thus more likely to use cash when a discount is offered. As was observed in the raw data, auto-related transactions had a significantly higher probability of receiving a cash discount: people who had all of their transactions in the auto sector had a 5.6 percent higher probability of receiving a cash discount than people who had no auto-related transactions.

The probability of receiving a debit card discount was 2 percent lower for highly educated consumers, even when controlling for income. Latino respondents were 1 percent less likely to receive a debit discount than non-Latino respondents. None of the merchant categories were significant in the debit discount regression, even though we included the housing-related category, although over 11 percent of debit card transactions in the housing-related category received discounts. 
In the credit card surcharge probit regression, only the number of transactions was statistically significant. The dummy variable for income below $\$ 25 \mathrm{~K}$ a year is omitted because no respondents in that income cohort experienced credit card surcharges, so the variable predicts failure perfectly. Because there are only 22 observations with a positive outcome, it is not surprising that these observations are spread over all of the demographic groups and that none of those coefficients is significant.

The diary asks respondents whether the transaction was conducted "in person" or "not in person." Although the "not in person" transaction could include mailing a check, we assume that the number of mail-in transactions is very small, because our analysis excludes bill payments. It is therefore reasonable to expect that the majority of the "not in person" transactions were conducted online. Of the total of 12,584 transactions in the cleaned diary dataset, only 6.5 percent were conducted not in person. Surcharging of credit card transactions is probably more common for online payments such as college tuition or local government bill payments, but these transactions can be classified as bills and we exclude bill payments from the sample. Because the share of not-in-person transactions is low, it is not surprising that when we estimate the discount or surcharge equations for in-person transactions only, the results are qualitatively similar to the results of the whole sample.

\section{Conclusion}

Policymakers need tools to be able to evaluate whether a given policy has had an effect in practice, and how that change has affected consumers. In this paper, we use data from a recent diary survey of consumer payment behavior to test whether merchants exercised their new freedoms to steer consumers' payment choice by either discounting or surcharging based on the method of payment.

We find almost no evidence that merchants have taken advantage of their new pricing flexibility so far: only a very small fraction of transactions were either discounted or surcharged. This could be a consequence of the slow adjustment process in which merchants interact with their customers. We intend to repeat this experiment in future diaries to analyze changes in 
discounting or surcharging practices by merchants. Future research should analyze whether and how consumers change their actions in response to merchants' pricing practices, assuming that merchants do change their pricing policies. 


\section{References}

Arango, C., K. Huynh, and L. Sabetti. 2011. "How Do You Pay? The Role of Incentives at the Point-of-Sale." Bank of Canada Working Paper 2011-23.

Barron, J. and Staten, M. and Umbeck, J. 1992. "Discounts for Cash in Retail Gasoline Marketing." Contemporary Economic Policy, 10(4): 89-102.

Bounie, D., and A. Francois. 2006. "Cash, Check or Bank Card? The Effects of Transaction Characteristics on the Use of Payment Instruments." Telecom Paris Economics and Social Sciences Working Paper No. ESS-06-05.

Briglevics, T., and O. Shy. Forthcoming. "Why Don't Most Merchants Use Price Discounts to Steer Consumer Payment Choice?" Review of Industrial Organization.

Ching, A., and F. Hayashi. 2010. "Payment Card Rewards Programs and Consumer Payment Choice." Journal of Banking and Finance 34(8): 1773-1787.

Foster, K., E. Meijer, S. Schuh, and M. Zabek, 2011. “The 2009 Survey of Consumer Payment Choice." Federal Reserve Bank of Boston, Public Policy Discussion Paper No. 11-1.

Grant, R. 1985. “On Cash Discounts to Retail Customers: Further Evidence.” Journal of Marketing 49(1): 145-146.

Ingene, C., and M. Levy. 1982. "Cash Discounts to Retail Customers: An Alternative to Credit Card Sales." Journal of Marketing 46(2): 92-103.

Klee, E. 2008. "How People Pay: Evidence from Grocery Store Data." Journal of Monetary Economics 55(3): 526-541.

Koulayev, Sergei, Marc Rysman, Scott Schuh, and Joanna Stavins. 2012. "Explaining Adoption and Use of Payment Instruments by U.S. Consumers," Federal Reserve Bank of Boston Working Paper No. 12-14.

Schuh, S. and J. Stavins. 2010. "Why Are (Some) Consumers (Finally) Writing Fewer Checks? The Role of Payment Characteristics," Journal of Banking and Finance 34(8): 1745-1758.

Schuh, S., O. Shy, J. Stavins, and R. Triest. 2012. "An Economic Analysis of the 2011 Proposed Settlement between the Department of Justice and Credit Card Networks." Journal of Competition Law and Economics 8(1): 107-144.

Shy, O. and J. Stavins. 2014. "Merchant Steering of Consumer Payment Choice: Lessons Learned from Consumer Surveys." Survey Methods: Insights from the Field.

Shy, O. 2013. “How Many Cards Do You Use?" Federal Reserve Bank of Boston Working Paper No. 13-13. 
Simon, J., K. Smith, and T. West. 2010. "Price Incentives and Consumer Payment Behavior." Journal of Banking and Finance 34(8): 1759-1772.

White, K. 1975. "Consumer Choice and Use of Bank Credit Cards: A Model and Cross-Section Results." Journal of Consumer Research 2: 10-18. 
Table 1: Summary statistics of the data

\begin{tabular}{|l|l|l|l|l|}
\hline & Full Diary & Steering Data & $\begin{array}{l}\text { Full } \\
\text { (Weighted) }\end{array}$ & $\begin{array}{l}\text { Steering } \\
\text { (Weighted) }\end{array}$ \\
\hline \# of transactions & 14,772 & 12,584 & $\mathrm{n} / \mathrm{a}$ & $\mathrm{n} / \mathrm{a}$ \\
\hline \# of individuals & 2,468 & 2,297 & $\mathrm{n} / \mathrm{a}$ & $\mathrm{n} / \mathrm{a}$ \\
\hline \# of total diary days & 7,404 & 5,230 & $\mathrm{n} / \mathrm{a}$ & $\mathrm{n} / \mathrm{a}$ \\
\hline \# of credit transactions & 2,657 & 2,538 & $\mathrm{n} / \mathrm{a}$ & $\mathrm{n} / \mathrm{a}$ \\
\hline \# of debit transactions & 3,605 & 3,355 & $\mathrm{n} / \mathrm{a}$ & $\mathrm{n} / \mathrm{a}$ \\
\hline \# of cash transactions & 5,777 & 5,678 & $\mathrm{n} / \mathrm{a}$ & $\mathrm{n} / \mathrm{a}$ \\
\hline Median amount & $\$ 18.95$ & $\$ 14.04$ & $\$ 19.00$ & $\$ 14.40$ \\
\hline Mean amount & $\$ 80.32$ & $\$ 32.63$ & $\$ 105.55$ & $\$ 32.81$ \\
\hline Median credit amount & $\$ 29.10$ & $\$ 27.99$ & $\$ 28.00$ & $\$ 26.30$ \\
\hline Mean credit amount & $\$ 67.58$ & $\$ 51.26$ & $\$ 71.44$ & $\$ 50.05$ \\
\hline Median debit amount & $\$ 21.94$ & $\$ 20.03$ & $\$ 22.97$ & $\$ 20.71$ \\
\hline Mean debit amount & $\$ 57.77$ & $\$ 36.16$ & $\$ 72.87$ & $\$ 37.51$ \\
\hline Median cash amount & $\$ 7.57$ & $\$ 7.39$ & $\$ 7.94$ & $\$ 7.60$ \\
\hline Mean cash amount & $\$ 20.95$ & $\$ 15.71$ & $\$ 29.06$ & $\$ 17.26$ \\
\hline
\end{tabular}

Source: 2012 Diary of Consumer Payment Choice

Note: "Full Diary" includes bill and automatic bill transactions. "Steering Data" excludes bill and automatic transactions, and shows the data used to generate the steering tables and regressions. The data in the last two columns are weighted using gender, age, ethnicity, education, household size, and household income to make the diary sample approximate the U.S. population. 
Table 2: Percentage of discounted or surcharged transactions by demographic variables

\begin{tabular}{|c|c|c|c|c|c|c|c|c|c|c|c|c|c|c|}
\hline & \multicolumn{5}{|c|}{ Cash Discount } & \multicolumn{4}{|c|}{ Debit Discount } & \multicolumn{5}{|c|}{ Credit Surcharge } \\
\hline & \multirow{2}{*}{$\begin{array}{c}\text { Percent } \\
\text { Yes }\end{array}$} & \multicolumn{4}{|c|}{ Median Amnt } & \multirow{2}{*}{$\begin{array}{c}\text { Percent } \\
\text { Yes }\end{array}$} & \multicolumn{3}{|c|}{ Median Amnt } & \multirow{2}{*}{$\begin{array}{c}\text { Percent } \\
\text { Yes }\end{array}$} & \multicolumn{4}{|c|}{ Median Amnt } \\
\hline & & & Yes & & No & & Yes & & No & & & Yes & & No \\
\hline Total & 1.7 & $\$$ & 20.00 & $\$$ & 7.49 & 1.8 & $\$ 27.95$ & $\$$ & 20.52 & 1.2 & $\$$ & 30.00 & $\$$ & 26.00 \\
\hline \multicolumn{15}{|l|}{ Age } \\
\hline Under 25 & 1.8 & $\$$ & 20.00 & $\$$ & 5.98 & 1.9 & $\$ 67.89$ & $\$$ & 15.01 & 6.4 & $\$$ & 67.89 & $\$$ & 15.01 \\
\hline $25-34$ & 1.2 & $\$$ & 40.00 & $\$$ & 8.31 & 1.6 & \$ 19.04 & $\$$ & 18.00 & 0.6 & $\$$ & 30.00 & $\$$ & 19.37 \\
\hline $35-44$ & 1.2 & $\$$ & 25.00 & $\$$ & 7.00 & 1.6 & $\$ 135.00$ & $\$$ & 19.03 & 3.2 & $\$$ & 64.00 & $\$$ & 26.11 \\
\hline $45-54$ & 1.6 & $\$$ & 35.00 & $\$$ & 7.40 & 2.4 & $\$ 20.00$ & $\$$ & 22.62 & 0.4 & $\$$ & 36.90 & $\$$ & 30.00 \\
\hline $55-64$ & 2.8 & $\$$ & 12.00 & $\$$ & 7.08 & 1.4 & \$ 24.44 & $\$$ & 26.75 & 0.4 & $\$$ & 26.33 & $\$$ & 31.76 \\
\hline Over 64 & 1.6 & $\$$ & 21.51 & $\$$ & 8.50 & 2.3 & \$ 33.96 & $\$$ & 25.37 & 0.9 & $\$$ & 26.25 & $\$$ & 28.69 \\
\hline \multicolumn{15}{|l|}{ Income } \\
\hline$<25 k$ & 2.8 & $\$$ & 15.00 & $\$$ & 9.32 & 1.0 & $\$ 22.75$ & $\$$ & 19.25 & 0.0 & $\$$ & - & $\$$ & 23.56 \\
\hline $25-49 k$ & 1.6 & $\$$ & 14.00 & $\$$ & 7.49 & 2.1 & \$33.96 & $\$$ & 21.00 & 1.6 & $\$$ & 26.25 & $\$$ & 25.00 \\
\hline $50-74 k$ & 1.6 & $\$$ & 21.51 & $\$$ & 6.50 & 2.1 & $\$ 19.04$ & $\$$ & 19.81 & 1.0 & $\$$ & 26.00 & $\$$ & 30.76 \\
\hline $75-99 k$ & 0.9 & $\$$ & 25.00 & $\$$ & 6.41 & 0.4 & $\$ 13.56$ & $\$$ & 20.00 & 0.5 & $\$$ & 36.90 & $\$$ & 21.71 \\
\hline $100-124 k$ & 1.2 & $\$$ & 48.00 & $\$$ & 6.50 & 3.3 & $\$ 135.00$ & $\$$ & 25.00 & 0.6 & $\$$ & 20.00 & $\$$ & 23.00 \\
\hline $125-199 k$ & 0.9 & $\$$ & 20.00 & $\$$ & 8.14 & 1.7 & $\$ 26.10$ & $\$$ & 26.32 & 2.5 & $\$$ & 64.00 & $\$$ & 30.00 \\
\hline$>200 k$ & 1.4 & $\$$ & 35.00 & $\$$ & 9.77 & 0.0 & $\$$ & $\$$ & 25.00 & 1.7 & $\$$ & 4.00 & $\$$ & 42.00 \\
\hline \multicolumn{15}{|l|}{ Education } \\
\hline Less HS & 2.8 & $\$$ & 14.00 & $\$$ & 7.00 & 4.4 & $\$ 135.00$ & $\$$ & 25.00 & 7.1 & $\$$ & 26.00 & $\$$ & 28.00 \\
\hline High School & 1.5 & $\$$ & 20.00 & $\$$ & 8.38 & 2.0 & $\$ 19.04$ & $\$$ & 22.82 & 1.5 & $\$$ & 64.00 & $\$$ & 24.12 \\
\hline Some College & 1.5 & $\$$ & 25.00 & $\$$ & 7.59 & 2.3 & $\$ 26.10$ & $\$$ & 20.31 & 2.3 & $\$$ & 20.00 & $\$$ & 26.00 \\
\hline College & 1.8 & $\$$ & 20.00 & $\$$ & 6.87 & 1.4 & $\$ 36.04$ & $\$$ & 19.81 & 0.5 & $\$$ & 50.00 & $\$$ & 27.00 \\
\hline Graduate & 1.4 & $\$$ & 35.00 & $\$$ & 6.50 & 0.3 & 0.75 & $\$$ & 20.00 & 0.6 & $\$$ & 36.90 & $\$$ & 28.36 \\
\hline \multicolumn{15}{|l|}{ Gender } \\
\hline Male & 1.5 & $\$$ & 20.00 & $\$$ & 6.85 & 2.0 & \$ 33.96 & $\$$ & 20.00 & 1.1 & $\$$ & 36.90 & $\$$ & 24.00 \\
\hline Female & 1.9 & $\$$ & 20.00 & $\$$ & 8.38 & 1.7 & $\$ 27.95$ & $\$$ & 21.55 & 1.3 & $\$$ & 26.25 & $\$$ & 30.00 \\
\hline \multicolumn{15}{|l|}{ Ethnicity } \\
\hline Latino & 2.0 & $\$$ & 20.00 & $\$$ & 9.26 & 1.7 & $\$ 49.50$ & $\$$ & 20.00 & 0.9 & $\$$ & 14.00 & $\$$ & 23.13 \\
\hline Not Latino & 1.6 & $\$$ & 20.00 & $\$$ & 7.00 & 1.8 & \$ 27.95 & $\$$ & 20.89 & 1.2 & $\$$ & 30.00 & $\$$ & 27.00 \\
\hline \multicolumn{15}{|l|}{ Race } \\
\hline White & 1.6 & $\$$ & 20.00 & $\$$ & 7.78 & 1.6 & $\$ 22.75$ & $\$$ & 20.86 & 1.2 & $\$$ & 30.00 & $\$$ & 27.16 \\
\hline Black & 1.6 & $\$$ & 20.00 & $\$$ & 7.00 & 3.3 & $\$ 26.10$ & $\$$ & 20.63 & 1.8 & $\$$ & 37.00 & $\$$ & 24.98 \\
\hline Asian & 1.4 & $\$$ & 40.00 & $\$$ & 6.00 & 0.0 & $\$$ & $\$$ & 20.00 & 0.4 & $\$$ & 49.36 & $\$$ & 21.13 \\
\hline Other & 2.4 & $\$$ & 20.00 & $\$$ & 7.51 & 2.5 & $\$ 135.00$ & $\$$ & 20.00 & 1.5 & $\$$ & 14.00 & $\$$ & 21.00 \\
\hline \multicolumn{15}{|l|}{ Location } \\
\hline In Person & - & & - & & - & 1.8 & \$ 27.95 & $\$$ & 20.00 & 1.2 & $\$$ & 26.33 & $\$$ & 25.00 \\
\hline Not In Person & - & & - & & - & 1.2 & $\$ 72.00$ & $\$$ & 36.92 & 0.9 & $\$$ & 93.00 & $\$$ & 40.32 \\
\hline
\end{tabular}

Source: 2012 DCPC

Note: Median Amount columns refer to the amount of the transaction. 
Table 3: Percentage of discounted or surcharged transactions by general merchant category

\begin{tabular}{|c|c|c|c|c|c|c|c|c|c|c|c|c|c|c|c|}
\hline & \multicolumn{5}{|c|}{ Cash Discount } & \multicolumn{5}{|c|}{ Debit Discount } & \multicolumn{5}{|c|}{ Credit Surcharge } \\
\hline & \multirow{2}{*}{$\frac{\text { Percent }}{\text { Yes }}$} & \multicolumn{4}{|c|}{ Median Amnt } & \multirow{2}{*}{$\frac{\text { Percent }}{\text { Yes }}$} & \multicolumn{4}{|c|}{ Median Amnt } & \multirow{2}{*}{$\frac{\text { Percent }}{\text { Yes }}$} & \multicolumn{4}{|c|}{ Median Amnt } \\
\hline & & & Yes & & No & & & Yes & & No & & & Yes & & No \\
\hline Total & 1.7 & $\$$ & 20.00 & $\$$ & 7.49 & 1.8 & $\$$ & 27.95 & $\$$ & 20.52 & 1.2 & $\$$ & 30.00 & $\$$ & 26.00 \\
\hline \multicolumn{16}{|l|}{ Merchant Type } \\
\hline $\begin{array}{r}\text { Food and Personal Care } \\
\text { Supplies }\end{array}$ & 0.8 & $\$$ & 6.00 & $\$$ & 6.29 & 1.5 & $\$$ & 22.75 & $\$$ & 15.00 & 0.7 & $\$$ & 26.00 & $\$$ & 18.00 \\
\hline Auto and Vehicle Related & 6.6 & $\$$ & 21.51 & $\$$ & 10.00 & 2.6 & $\$$ & 36.30 & $\$$ & 32.04 & 4.5 & $\$$ & 64.00 & $\$$ & 37.40 \\
\hline General Merchandise & 3.5 & $\$$ & 16.00 & $\$$ & 9.06 & 1.7 & $\$$ & 22.78 & $\$$ & 30.00 & 0.1 & $\$$ & 37.00 & $\$$ & 42.19 \\
\hline $\begin{array}{r}\text { Entertainment and } \\
\text { Transportation }\end{array}$ & 1.6 & $\$$ & 75.00 & $\$$ & 10.00 & 1.0 & $\$$ & 0.75 & $\$$ & 30.00 & 0.0 & $\$$ & - & $\$$ & 34.00 \\
\hline Housing Related & 0.0 & $\$$ & - & $\$$ & 24.69 & 11.3 & & 135.00 & $\$$ & 50.00 & 0.6 & & 150.00 & $\$$ & 38.17 \\
\hline $\begin{array}{r}\text { Medical, Education, Person } \\
\text { Services }\end{array}$ & 1.2 & $\$$ & 80.00 & $\$$ & 15.00 & 1.6 & $\$$ & 11.00 & $\$$ & 34.36 & 0.0 & $\$$ & - & $\$$ & 39.81 \\
\hline $\begin{array}{r}\text { Financial, Professional, } \\
\text { Miscellaneous Services }\end{array}$ & 1.9 & $\mathbf{\$}$ & 40.00 & $\$$ & 8.75 & 0.0 & $\$$ & - & $\$$ & 16.20 & 5.0 & $\mathbf{\$}$ & 26.33 & $\mathbf{\$}$ & 19.95 \\
\hline Government and Nonprofit & 0.0 & $\$$ & - & $\$$ & 6.00 & 0.0 & $\$$ & - & $\$$ & 65.00 & 0.0 & $\$$ & - & & 100.00 \\
\hline Gifts and Trasfers to People & 0.0 & $\$$ & - & $\$$ & 15.00 & 0.0 & $\$$ & - & $\$$ & 21.66 & 0.0 & $\$$ & - & $\$$ & 68.37 \\
\hline I don't know & 0.0 & $\$$ & - & $\mathbf{\$}$ & 8.00 & 2.6 & $\$$ & 6.64 & $\$$ & 10.79 & 0.0 & $\$$ & - & $\$$ & 25.00 \\
\hline
\end{tabular}

Source: 2012 DCPC

Note: Median Amount columns refer to the amount of the transaction. 
Table 4: Number of respondents by the number of cash discounts, debit card discounts, and credit card surcharges they receive

\begin{tabular}{lccc}
\hline \hline & Cash & Debit & Credit \\
\hline 0 & 2209 & 2249 & 2276 \\
1 & 74 & 43 & 20 \\
2 & 12 & 5 & 1 \\
3 & 1 & & \\
4 & 1 & & \\
\hline Total & 2297 & 2297 & 2297 \\
\hline \hline
\end{tabular}

Source: 2012 DCPC 
Table 5: Marginal effects from three probit regressions

Dependent variable $=1$ if a respondent received a cash discount, a debit card discount, or a credit card surcharge.

\begin{tabular}{|c|c|c|c|}
\hline & Cash (Discount) & Debit (Discount) & Credit (Surcharge) \\
\hline num_trans & $0.00360^{* * *}$ & $0.00333^{* * *}$ & $0.00110^{* *}$ \\
\hline adopt_debit (d) & -0.0111 & & \\
\hline adopt_credit (d) & -0.00969 & & \\
\hline age_u25 (d) & -0.0152 & 0.0137 & 0.0733 \\
\hline age_2534 (d) & -0.00995 & -0.00178 & 0.00176 \\
\hline age_3544 (d) & -0.00716 & 0.00126 & 0.00291 \\
\hline age_5564 (d) & 0.0133 & -0.00190 & -0.00165 \\
\hline age_o64 (d) & 0.000654 & 0.0181 & -0.00132 \\
\hline edu_lhs (d) & 0.0146 & 0.00507 & 0.220 \\
\hline edu_hs (d) & -0.00687 & 0.00181 & 0.00526 \\
\hline edu_sc (d) & -0.00994 & 0.0133 & 0.00342 \\
\hline edu_pgs (d) & -0.00624 & $-0.0205^{* * *}$ & 0.00646 \\
\hline hh_size & 0.000518 & 0.000776 & 0.000555 \\
\hline latino (d) & 0.0129 & $-0.0117^{*}$ & -0.000726 \\
\hline white (d) & -0.00836 & -0.0189 & -0.00269 \\
\hline male (d) & 0.00663 & 0.00751 & -0.000296 \\
\hline inc_LT25 (d) & $0.0379^{* *}$ & -0.00849 & \\
\hline inc_2549 (d) & 0.00930 & -0.00263 & 0.00116 \\
\hline inc_7599 (d) & -0.00729 & $-0.0132^{*}$ & 0.00327 \\
\hline inc_GT100 (d) & -0.00414 & -0.00532 & 0.00137 \\
\hline employed (d) & 0.00661 & -0.00149 & -0.0102 \\
\hline per_food & 0.00433 & & 0.00290 \\
\hline per_auto & $0.0556^{* * *}$ & 0.0134 & 0.0149 \\
\hline per_general & 0.0194 & 0.0252 & -0.0142 \\
\hline per_housing & & 0.0218 & \\
\hline$N$ & 2290 & 1544 & 1212 \\
\hline Pseudo R-squared & .08 & .09 & .27 \\
\hline
\end{tabular}

Marginal effects

(d) for discrete change of dummy variable from 0 to 1

${ }^{*} p<0.10,{ }^{* *} p<0.05,{ }^{* * *} p<0.01$

Source: Authors' calculations based on the 2012 DCPC 
Figure 1: Percentage of cash and debit card transactions receiving a discount, by value range
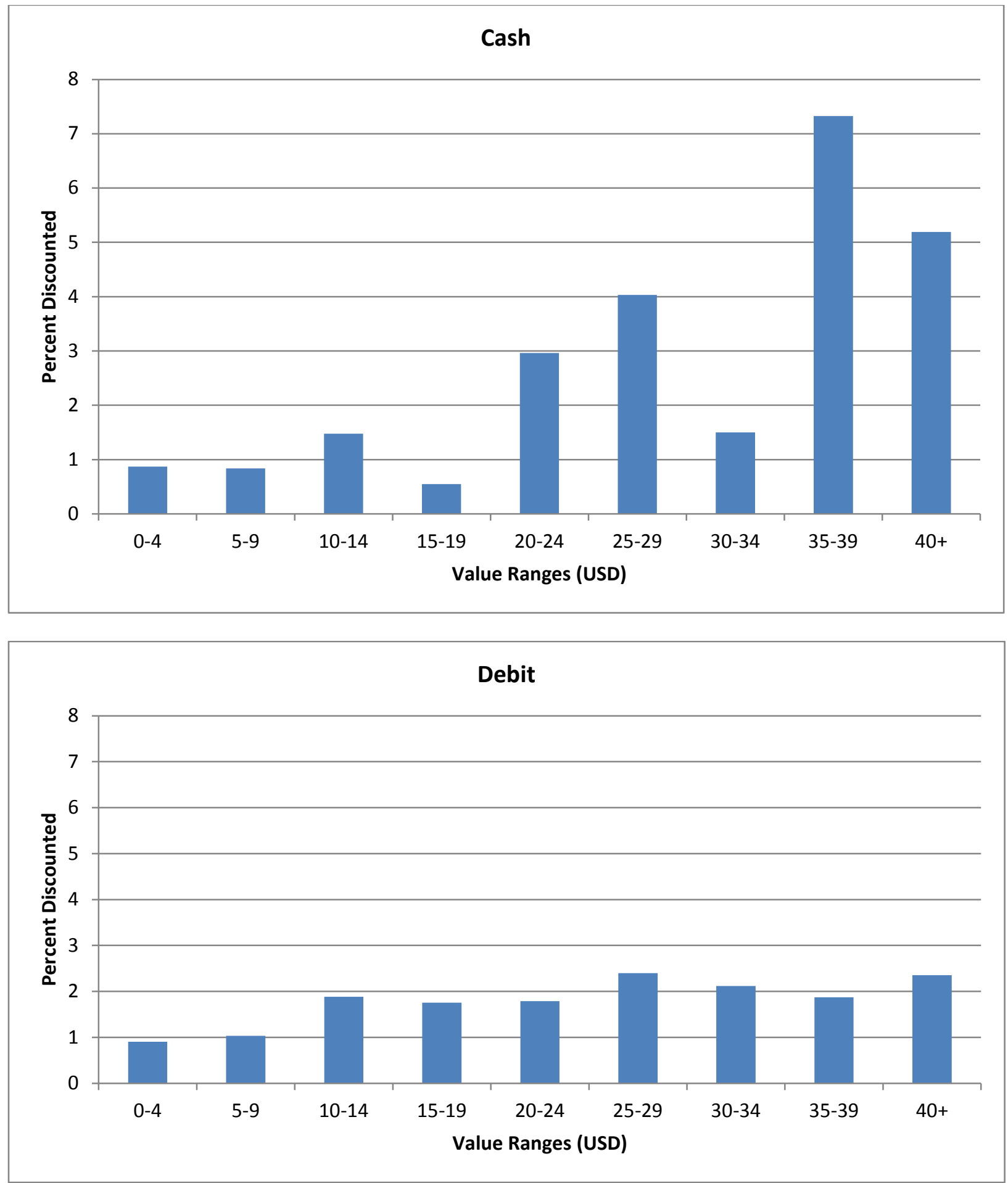

Source: 2012 DCPC 
Appendix: Breakdown of broad merchant categories

\begin{tabular}{|c|c|}
\hline \multirow{3}{*}{ Food and Personal Care Supplies } & Fast food, food service, food trucks, snack bars \\
\hline & $\begin{array}{l}\text { Grocery, pharmacy, liquor stores, convenience stores } \\
\text { (without gas stations) }\end{array}$ \\
\hline & Restaurants, bars \\
\hline \multirow{6}{*}{ Auto and Vehicle Related } & Auto maintenance and repair \\
\hline & Auto rental and leasing \\
\hline & Auto vehicle and parts dealers \\
\hline & Gas stations \\
\hline & Parking lots and garages \\
\hline & Tolls \\
\hline \multirow{5}{*}{ General Merchandise } & Clothing and accessories stores \\
\hline & $\begin{array}{l}\text { Department and discount stores and websites, } \\
\text { wholesale clubs and websites }\end{array}$ \\
\hline & Online shopping \\
\hline & $\begin{array}{l}\text { Other stores (book, florist, hobby, music, office supply, } \\
\text { pet, sporting goods) }\end{array}$ \\
\hline & Vending machines \\
\hline \multirow{5}{*}{ Entertainment and Transportation } & Entertainment, recreation, arts, museums \\
\hline & Hotels, motels, RV parks, camps \\
\hline & Movie theaters \\
\hline & $\begin{array}{l}\text { Phone/internet (wired/wireless/satellite), online and } \\
\text { print news, online games }\end{array}$ \\
\hline & Transportation (includes public transportation) \\
\hline \multirow{8}{*}{ Housing Related } & $\begin{array}{l}\text { Building contractors (electrical/plumbing/HVAC, tile, } \\
\text { painting, etc.) }\end{array}$ \\
\hline & Building services \\
\hline & Electric, natural gas, water and sewage \\
\hline & $\begin{array}{l}\text { Furniture \& home goods stores, appliance \& electronics } \\
\text { stores, hardware \& garden stores }\end{array}$ \\
\hline & Heating oil dealers, propane dealers \\
\hline & Rent, real estate agents and brokers \\
\hline & Mortgage \\
\hline & Trash collection \\
\hline \multirow{6}{*}{ Medical, Education, Person Services } & $\begin{array}{l}\text { Child care, elder care, youth and family services, } \\
\text { emergency and other relief services }\end{array}$ \\
\hline & Doctors, dentists, other health professionals \\
\hline & Education \\
\hline & Hospitals, residential care \\
\hline & $\begin{array}{l}\text { Personal care, dry cleaning, pet grooming and sitting, } \\
\text { photo processing, death care }\end{array}$ \\
\hline & Veterinarians \\
\hline \multirow{5}{*}{$\begin{array}{l}\text { Financial, Professional, } \\
\text { Miscellaneous Services }\end{array}$} & $\begin{array}{l}\text { Employment services, travel agents, security services, } \\
\text { office administrative services }\end{array}$ \\
\hline & Financial services, insurance \\
\hline & Legal, accounting, architectural, and other prof. services \\
\hline & Mail, delivery, storage \\
\hline & Rental centers \\
\hline
\end{tabular}




\begin{tabular}{|c|l|}
\hline \multirow{2}{*}{ Government and Nonprofit } & $\begin{array}{l}\text { Repair/maintenance of electronics and personal and } \\
\text { household goods }\end{array}$ \\
\hline \multirow{2}{*}{ Gifts and Transfers to People } & $\begin{array}{l}\text { Charitable, religious, professional, civic (not } \\
\text { government) organizations }\end{array}$ \\
\cline { 2 - 2 } & Taxes fees, fines and other payments to governments \\
\cline { 2 - 2 } & Friends and family \\
\cline { 2 - 2 } & People who provide goods and services \\
\hline I don't know & Other people \\
\hline & I don't know \\
\hline
\end{tabular}

Source: 2012 DCPC 